\title{
Naturalising Empire: Echoes of Mackinder for the Next American Century?
}

\author{
GERRY KEARNS \\ Department of Geography, University of Cambridge, UK
}

\begin{abstract}
At the start of the twentieth century, Halford Mackinder's geopolitical writings provided a powerful justification for British imperialism. He presented imperialism as a force of nature by emphasising historical rupture, essential conflict and geopolitical strategy. A century later, these same themes re-appear in contemporary accounts of our new world order and serve now to naturalise the imperial mission of the United States. A critical examination of the theses of Mackinder can aid in challenging the presumptions of the new imperialists.
\end{abstract}

The centenary of Halford Mackinder's (1861-1947) 'Geographical pivot' paper has been celebrated with historical and modern evaluations. ${ }^{1}$ The article itself has been republished, together with the discussion that followed its delivery and some modern alternatives. ${ }^{2}$ There is a new collection of essays on the legacy of Mackinder. ${ }^{3}$ In December 2004 Nick Megoran organised a meeting in Tashkent to discuss the relevance of the heartland concept for understanding the dilemmas of the countries of the former Soviet Union. ${ }^{4}$ Paul Kennedy has praised Mackinder's prescience (as also that of Leo Amery in the contemporary discussion). ${ }^{5}$ Mackinder's writings have been invoked with regularity by those who believe that contemporary strategists are too idealistic in ever projecting a world at peace with itself. Writing to tell Mackinder that the American Geographical Society was to award Mackinder its Charles P. Daly medal, Isaiah Bowman praised the British geographer's 'courage and foresight in publishing "Democratic Ideals and Reality" at a time when the world in general was beguiling itself with the thought that we had concluded a war to end war. ${ }^{6}$ Further, Bowman drew from Mackinder the lesson that the safety of Europe required that Germany and Russia be endlessly pitted one against

Address correspondence to Gerry Kearns, Department of Geography, University of Cambridge, UK. E-mail: gk202@hermes.cam.ac.uk 
the other. ${ }^{7}$ Mackinder's injunction to contain Russia has marched through geostrategic writings ever since. ${ }^{8}$ Democratic Ideals and Reality: a Study in the Politics of Reconstruction, first published in London and New York in 1919, has seen further US editions in 1942, 1962, 1981 and 1996.' With each new edition comes an introduction insisting upon Mackinder's continued relevance. Mackinder was flattered by the attention given his work during the Second World War, referring with ironic self-deprecation to the book 'which I wrote in the six weeks following the Armistice of 1918. ${ }^{, 10}$ It was to his 1904 paper, that he wished to refer his admirer Hans Weigert for 'my views were already taking shape away back in 1904, and have not been formed in a hurry. ${ }^{11}$ As Mackinder was all too painfully aware, it was this early paper on which 'Haushofer based himself originally.' ${ }^{12}$ There are differences of strategic emphasis across Mackinder's various versions of his geopolitical vision but there is, I believe, a consistent structure of argument.

In this paper, I want to focus on three discursive strategies that allow Mackinder's work to carry political significance. ${ }^{13}$ They are, first, the identification of a recent historical rupture underlining the urgency of a contemporary crisis. For Mackinder, this historical break announced a new closed-space world. Henceforth, no part of the world could be ignored by British strategists. In a closed-space world, the British had a legitimate interest in the affairs of every single part of the globe. Secondly, there is the characterisation of global politics as essentially a zero-sum game in which fundamentally incompatible human aggregates confront each other. Finally, the global conflict is understood as played out through territorial strategies that prioritise control over natural resources. I want to suggest that in some ways we can see these intellectual tactics as allowing Mackinder to present the British Empire as organic entity facing an immediate geostrategic crisis. In a blend of free-will and determinism, characteristic of much environmentalist thinking, ${ }^{14}$ Mackinder presented British imperialism as a rationally directed force of nature. The emphasis on free will was necessary to alert the British, or at least the Anglo-Saxon, people to their momentous obligations. For Mackinder, the British Empire had to 'hold its place according to the universal law of survival through efficiency and effort.' ${ }^{15}$ The British had to rise about the 'mere fatalism' of the seemingly inevitable cycle of the rise and decline of empires. ${ }^{16}$ The references to nature made this a question of national, or racial, survival, rendering moot questions about the morality of Empire. Nature, and the realpolitik to which it gave rise, was the reality challenging purely idealistic notions of global fairness. The piety of paper constitutions had to yield before the power-play of material forces. Much current debate about the post-Cold-War New World Order seems to offer similar prescriptions and does so by adopting, although rarely explicitly, three discursive strategies evident in Mackinder's work. It is because these arguments lend support to imperialist activity that they prove so attractive 
to imperialists, past and present. Beyond the direct influence of Mackinder on some strategists, there is a broader penumbra or thinkers who naturalise empire in broadly similar ways to Mackinder without, perhaps, having been directly influenced by his writings. In their treatment of historical caesura, global conflict and global strategy, there are a number of modern theorists who naturalise an American Empire and a supporting role for the United Kingdom alongside the United States. With hindsight, it is clear, at least to me, that there were serious difficulties with Mackinder's attempt to urge Anglo-Saxon hegemony as the natural path for Britain and its allies. I think that similar issues are raised by current advocacy of a second American century.

\section{A BREAK IN HISTORY}

For Mackinder, the world of the early twentieth-century was entering a new phase, a new closed-space existence in which events in any one part of the world reverberated everywhere else, 'we have now a closed circuit - a machine complete and balanced in all its parts. Touch one and you influence all.' ${ }^{17}$ There were no more empty lands, 'a surrounding circuit of unknown space and barbaric chaos,' to act as a safety valve for European rivalries. ${ }^{18}$ Now, all across the world, the Great Powers faced up to each other in competition for trade, markets, resources and military allies. The survival of British power required that it exert its influence over all parts of the globe. Events in each part of the world were the legitimate concern of the British because those events would have consequences elsewhere, including upon the British. The "post-Columbian age'19 presented new problems and the laissez-faire attitudes of the Victorian era would no longer do. The old liberal policies of non-interference in the affairs of foreign countries, often honoured more in word than deed, were no longer adequate. Likewise, free markets, either globally or domestically, were simply too likely to be abused by other, less-liberal national economies. The British people required social reform and racial purity at home, protection of domestic markets and industries, unity among all the far-flung British peoples be they in England, Canada, Australia or the United States, and, finally, so friendly an administration of the colonies that the British could count upon their 'dark man-power' ${ }^{20}$ in the struggle to come. This bundle of policies promised a 'reconciliation of Colonial Liberalism with protection, the exclusion of coloured races and imperialism. ${ }^{21}$ At the time, there were many who could see very little that was liberal in any of this. For example, John Hobson saw the very pursuit of empire as a rejection of the Nonconformist Liberal tradition that had opposed slavery and promoted trade as an antidote to war. ${ }^{22}$ The transition from the Columbian to the post-Columbian periods marks, for Mackinder, a shift from an era in which European powers 
could more or less ignore each other as they grew naturally into new spaces consonant with their developing technological and demographic might, to a new era where statecraft was suddenly vital. The new world order would have to be fought over and would not spontaneously develop as the result of European growth overseas.

There are three difficulties with this account of world history and its new departure. In the first place, it ignores the agency involved in the creation of European empires in the so-called Columbian era. The Europeans did not simply spread into empty space overseas. They took these spaces; in some cases driving away or killing the aboriginal peoples and in all cases reshaping local ecologies and economies to their own ends. In almost every case, trade and flag went together, that is traders and soldiers, settlers and armies went together into new lands, creating chaos of their own before imposing order of their own. In the second place, this gives rise to a very ahistorical account of global inequality. In place of European agency in coercing peoples into new arrangements, we are presented with global inequality as a natural set of initial conditions, environmentally determined. Yet slavery in some places, imperial taxes and new property relations in others produced poverty for some as it garnered wealth for others. The circumstances facing Europeans abroad by 1900 can only be understood in the light of this much longer history. The development question of the twentieth century was a legacy of earlier colonialism. ${ }^{23}$ Finally, this view of history overstated the extent and abruptness of recent changes. The relations between Europe and the rest of the world were no zero-sum game after 1904. Colonialism, or the process that Harvey has called 'accumulation by dispossession, ${ }^{24}$ continued after 1904. Europeans could still extract new resources from new spaces without having to enter into wars with each other to secure them.

Something very similar to this closed-space thinking is found in much current geostrategic thinking. Robert Cooper has been a foreign policy advisor to Tony Blair and also Britain's ambassador to West Germany. He calls for 'a new kind of imperialism, one acceptable to a world of human rights and cosmopolitan values. ${ }^{25}$ In an odd echo of Mackinder's Colonial Liberalism, this new Euro-American benign global rule is to be a Liberal Imperialism. Cooper speaks of the ancient world in much the same way that Mackinder spoke of the Columbian one: 'in the ancient world, order meant empire. Those within the empire had order, culture and civilisation. Outside it lay barbarians, chaos and disorder. ${ }^{26}$ His closed-space thinking is explicit: 'in an age of globalisation no country is an island. Crises in Kashmir, the Middle East or the Korean Peninsula affect security in every continent and are the concern of everybody. ${ }^{27}$ In 2002 as in 1904, we have a geostrategical vision that invokes a recent change to a closed-space world to urge that laissez-faire geopolitics be set aside for a more assertive stance. For Cooper, as for Blair, the twin threats are weapons of mass destruction in the hands 
of unfriendly powers, and fanatical terrorists issuing forth from the 'chaotic' spaces that result when states 'collapse. ${ }^{28}$

For Cooper the new crisis arises from the end of the Westphalian age (1648-1989). ${ }^{29}$ In the Westphalian age, Europe was organised as a series of nation states. In turn, these nation states had organised much of the rest of the world as a series of colonies. Now, Western Europe is moving towards a post-modern state where sovereignty is shared between a number of states. At the other extreme, in Africa people struggle to create something resembling strong nation states out of the chaotic soup of post-colonialism. Figure 1

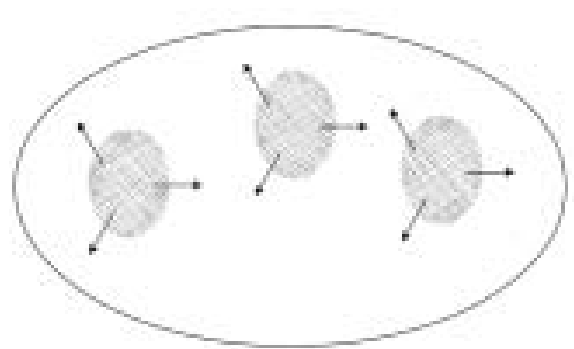

a. Antiquity

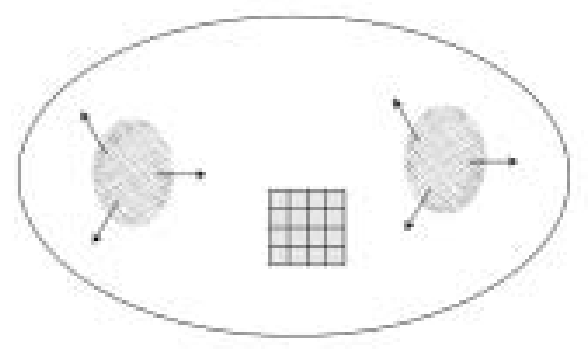

b. Rise of Europe

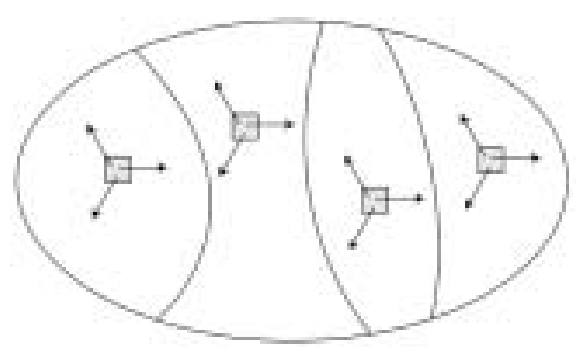

c. European colonialism

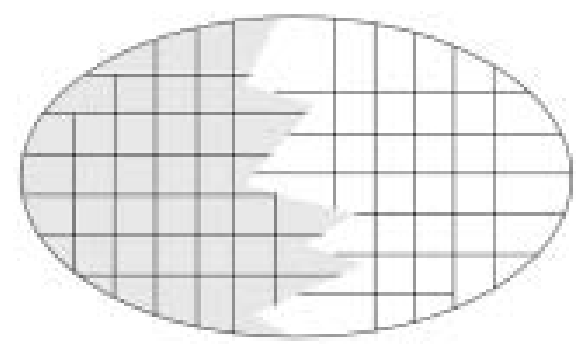

d. Cold War

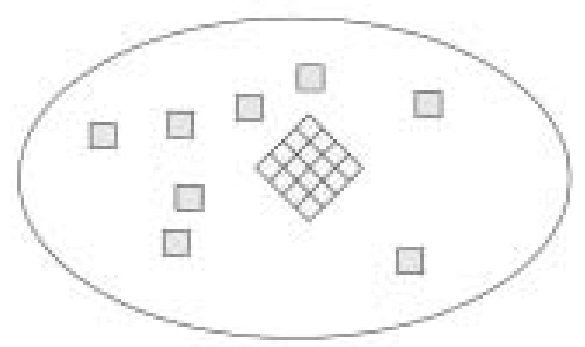

e. New World Order

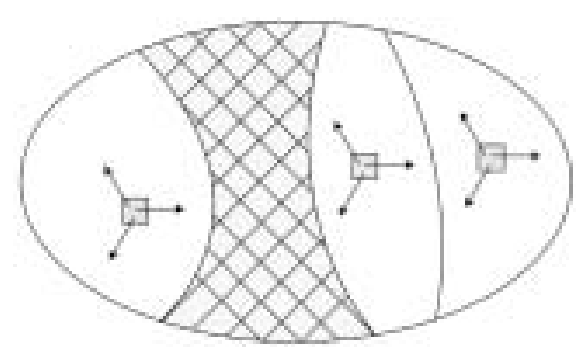

f. Liberal Imperialism

FIGURE 1 A schematic representation of Cooper's account of the evolution of the world order of pre-modern, modern and post-modern state forms. 
is a schematic representation of the historical geography implicit in Cooper's work. In Antiquity, there were a number of empires (shown as ovals with expansionary arrows) and within them there was order and regularity, outside there was barbaric chaos. The empires tried to extend their order to newer places. At some point, a modern nation-states system (shown as squares in Figure 1b) developed in Europe and on this basis, the Europeans gradually colonised most of the rest of the world (Figure 1c) bringing order where previously there had only been pre-modern anarchy. After the Second World War, the Europeans gradually withdrew from their colonies, which were then incorporated into the bipolar world of the Cold War (Figure 1d) where one set of capitalist states faced other socialist states. The Cold War "froze Europe for forty years. ${ }^{30}$ In Europe, there is a new experiment in pooling sovereignty and Cooper suggests that this sees the emergence of a postmodern system of states (represented as diamonds in Figure 1e). Outside Europe, modern states exist amidst a chaos of pre-modern (failed), post-colonial and post-socialist states. Cooper would like the modern and post-modern states to adopt sections of this chaos and offer them the protection of either a Liberal Imperialism, or the extension of a pooled sovereignty. In this spirit, Figure 1f shows an expanded area of pooled-sovereignty post-modern states and then a series of empires in the rest of the world.

The collapse of the Soviet Empire in Eastern Europe is understood by many as a break in history. For many, it is as if a real historical process could begin again after its socialist interregnum. Robert Kaplan, at one time Bill Clinton's favoured geostrategic thinker, suggests that Eastern Europe reentered history in 1989. ${ }^{31}$ Misha Glenny, from a very different perspective, also speaks of the rebirth of history in the region. ${ }^{32}$ With the loosening of the ice grip of the Soviet Empire, they suggest, East European ethnicities could once again assert their primordial identities in bloody civil war. Similar arguments are made about post-colonial Africa where tribalism, not ethnicity, is highlighted. Again, this is very like Mackinder, identities are naturalised and are naturally in conflict. The problems are likewise similar. The active agency of many parties in creating and re-creating ethnicity is elided. For Yugoslavia this means ignoring Tito's policy of fostering regional identities as a divide-and-rule strategy. ${ }^{33}$ Much the same happened in the Soviet Union. ${ }^{34}$ Serbian nationalism was not primordial, it was cultivated by Milosevic and his clique. ${ }^{35}$ Gaining power in the name of ethnic Serbs these people could line their pockets during the unsteady creation of private property and associated laws out of state socialism and political policing. Djilas had anticipated this insisting that 'this is not classical nationalism but a more dangerous, bureaucratic nationalism built on economic self-interest. ${ }^{36}$

Evoking a historical break to naturalise hegemony is nowhere clearer than in the work of Francis Fukuyama. In 1989 he was a member of the Policy Planning Staff of the US Department of State and his essay on the significance of 
the momentous changes of that year was entitled 'The End of History?'37 The essay reflected the triumphalism of Reaganite foreign policy after the fall of the Berlin Wall. Fukuyama's argument was that the fall of communism meant that all alternatives to democratic capitalism had now been rejected. 'Today,' he wrote, 'we who live in stable, long-standing liberal democracies ... have trouble imagining a world that is radically better than our own, or a future that is not essentially democratic and capitalist. ${ }^{38}$ History, as progressive change, could continue, but history as the evolution of ideal political and economic forms was over. All over the world, people want, and largely have got, liberal democracies. Fukuyama adds that alongside democracy, 'liberal principles in economics' have also spread 'and have succeeded in producing unprecedented levels of material prosperity, both in industrially developed countries and in countries that had been, at the close of World War II, part of the impoverished Third World. ${ }^{39}$ Figure 2 shows the way the End of History has come about. On one side there is a uniformity

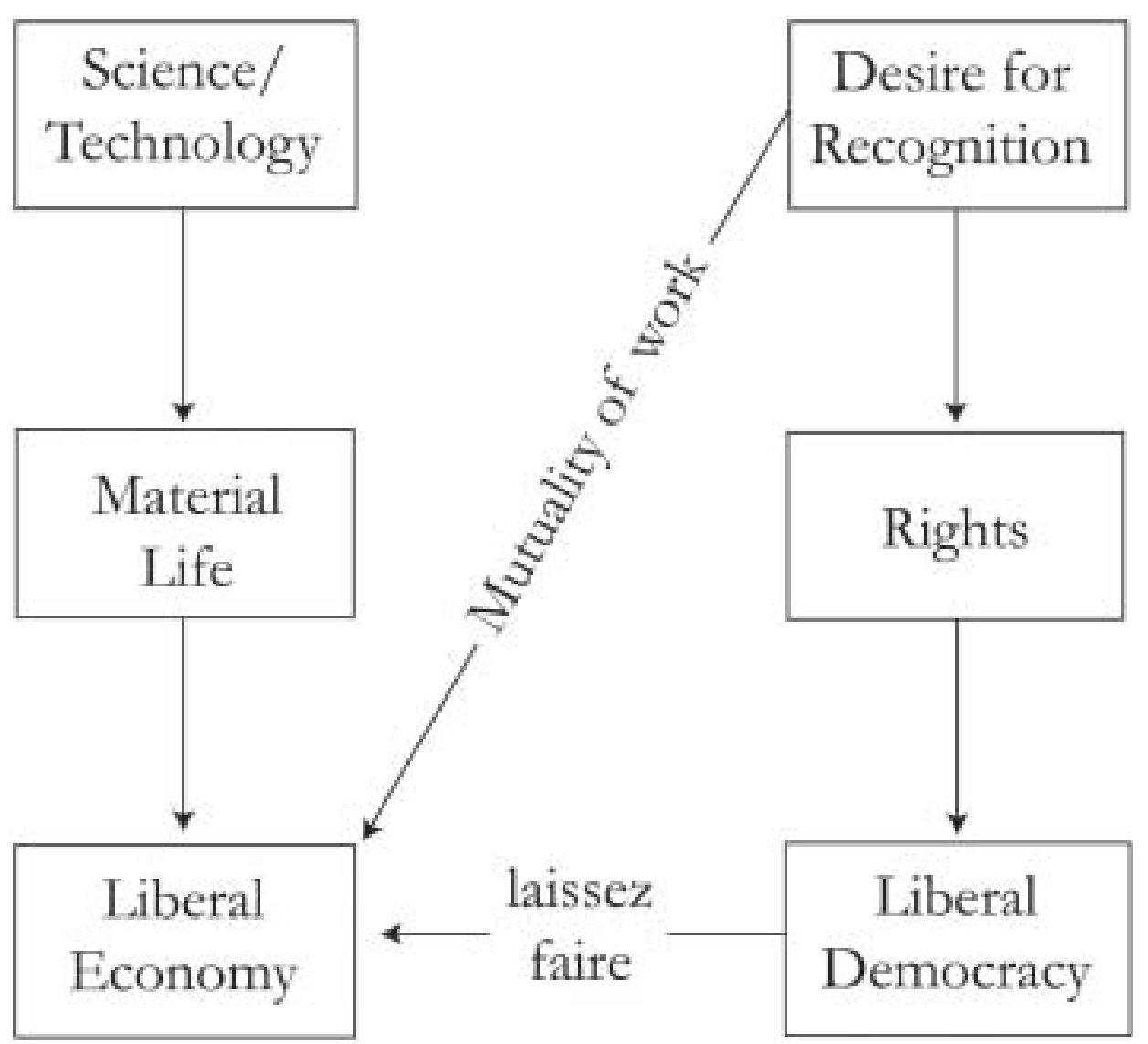

FIGURE 2 Fukuyama's account of the evolution of the hegemonic liberal society. 
of material life that comes from the use of a common science and common technology across all economies. On the other, the pursuit of the innate human desire for mutual recognition produces a general desire for rights as the form in which this mutual respect could be secured. In economic terms, a liberal economy allows people to find mutual recognition through valuing the work that they each do. Democracy also reinforces capitalism by providing a further justification for the freedom of the market.

Note, here, that liberalisation is an automatic, autonomous process that unfolds within states and spreads merely by force of example. Note also, that economic and political equality are elided. In the face of the racial inequalities in the United States, Fukuyama is content to that argue that, in the United States, addressing injustices based on sexuality or unequal capacity is due to 'the smallness of its actual remaining inequalities. ${ }^{40}$ Identity, then, is the form that recognition-seeking takes when economic equality has been substantially achieved. Fukuyama recognises that there are substantive inequalities relating to housing but he does not mention poverty and, because he cannot imagine an alternative to free markets, he will not accept that formal rights are seriously compromised by substantive inequalities. In global terms, treating states in isolation and presenting the Cold War as about ideas and not about resources means he has far too benign a view of global capitalism. In post-colonial societies, free markets and liberal economics meant preserving the property relations established through colonial theft. In place after place, decolonisation was shaped by anxieties about nationalisation or indigenisation of land and raw materials. ${ }^{41}$ Capitalism in the ex-colonies rested upon a particular allocation of property rights, ensuring access to markets and resources for American and British business. Anglo-Saxon hegemony today takes the form of UK/US plc., at least in the global extractive industries. Asymmetries are maintained through coercion. Fighting totalitarianism meant sustaining military juntas who were friendly to UK/US plc. even where populist alternatives, abused as communist, were merely nationalist and had been democratically elected. Despite Fukuyama's arguments about convergence, in fact liberal democracy and liberal economy have as often been in conflict as in harmony throughout the post-colonial Third World. ${ }^{42}$

\section{GLOBAL CONFLICT}

The creation and maintenance of free markets and the hegemonic property relations sustaining UK/US plc. requires active intervention through the IMF, the World Bank, the WTO, Structural Adjustment Policies, and colonialist wars to displace regimes that defy US hegemony. ${ }^{43}$ In Kosovo, for example, a humanitarian crisis was invoked by Blair as justification for bombing, yet while Germany received 20,000 refugees from the region, Britain accepted but $300 .{ }^{44}$ The majority of human rights abuses in Kosovo date from the 
period after NATO bombing began and continued into the period of NATO occupation. ${ }^{45}$ Pilger notes that in 1999, at the Davos summit, Blair's main complaint about Milosevic was that he was dragging heels over the liberalisation of the Serbian economy. He goes on to point out that at the Rambouillet peace conference the NATO conditions for not bombing included the requirement that all Serbian government assets be privatised. ${ }^{46}$ During the NATO occupation the most precious of these were seized:

'The jewel is the enormous Trepca [lead] mine complex, whose 1997 value was estimated at $\$ 5 \mathrm{bn}$. In an extraordinary smash and grab raid soon after the war, the complex was seized from its workers and managers by more than 2,900 Nato troops, who used teargas and rubber bullets. ${ }^{47}$

With the removal of Milosevic a new privatisation law was passed that replaced an earlier stipulation that $70 \%$ of state assets should be sold to workers with a new arrangement under which only 15\% is reserved for workers and up to $70 \%$ can go to foreign investors. The new government has also signed up to all the financial disciplines demanded by the World Bank. Fukuyama's account of the end of history hides this within a progressive vision of the unfolding of Liberalism. Yet, it does so almost too completely because it legitimates few of these interventions. In one sense, this is what worried Samuel Huntington and prompted him to write 'The Clash of Civilizations? ${ }^{48}$ Huntington had been director of security planning for the National Security Council in the Carter administration, was a founding editor of Foreign Affairs and is currently chair of the Harvard Academy for International and Area Studies. For Huntington, there is not enough urgency in Fukuyama. Huntington returns to a geopolitical vision much closer to Mackinder's vision of recently intensified global conflict. For Mackinder, the fundamental units of the world order were not nations. Behind nations there were races. These races had different proclivities with regards to political values, indeed varying capacities for self-government. He insisted that the English race, the English blood, is valuable as carrying a certain character. ${ }^{49}$ Only a world order under the tutelage of the diasporic British could safely oversee the introduction of democracy among the lesser races. To preserve this God-given hegemony, the United Kingdom needed a military alliance with the United States and a protectionist ring around its Empire. The resources beneath the feet of lesser races could not be left for them to squander but should instead be exchanged for the products of British factories. The strength of the Anglo-Saxon race depended upon its purity and there should thus be immigration- and, indeed, eugenic-controls in Britain. ${ }^{50}$

It is easy, and necessary, to characterise this as racist, but we need to identify the components of that racism if we are to attend to the echoes of Mackinder today. In the first place, it treats race as immutable and as determining of culture. Secondly, it assumes there is a stable hierarchy of races. 
Thirdly, racial contact is taken to be weakening of the superior race. Finally, the races are thought to be naturally and continually in conflict. The superiority of the European races was self-evident to Mackinder and the "external barbarism' of such as the Slavs acted in the manner of a 'repellent personality' that 'performs a valuable social function in uniting his enemies. ${ }^{51}$

A very similar, and equally paranoid, vision is at the heart of Huntington's work. Like Fukuyama, he converted his original article into a book, likewise dropping the question mark from the title in the process. He begins with a closed-space premise. 'The world,' he says, 'is becoming a smaller place. ${ }^{52}$ With greater contact, comes, he believes, a heightened awareness of cultural difference and an increased anxiety about those differences. These differences, then, have only become apparent since the globalisation of contacts after 1500. Geopolitics, he believes, has moved progressively from involving clashes between princes, through clashes between nation states, through the clash of ideologies during the Cold War to the new current phase. Much of this echoes Fukuyama but for Huntington the end of the ideological war heralds not a liberal world order of capitalism and democracy but another round of (differently constituted) global conflict. With ideological differences buried, he argues that the pertinent global differences will be cultural. Indeed, 'The fault lines between civilizations will be the battle lines of the future. ${ }^{53}$ Civilisations, for Huntington, are the fundamental divisions of the human race. They are primarily cultural and have been shaped by history. Religion is generally at their core and they have markedly different preferences when it comes to political institutions and systems. As the geographical context of people's lives broadens they lose localist attachments and re-invigorate fundamentalist religions. Furthermore, global contact between elites makes them more aware of these religious divisions leading them to cleave ever more strongly to indigenous belief systems. Huntington divides the world into nine religiously based civilisations (he is not really sure if Africa has any distinct civilisation) and he offers a map of these divisions based on groups of countries. ${ }^{54}$ Trade is becoming increasingly confined to regional blocs focused on civilisations. Huntington believes that you can neither choose nor change your civilisation and that it's your fate to have a certain identity together with the values that flow from that.

Only Western, Christian civilisation is engaging with arms reduction. All other peoples believe in expansionism if they can get away with it. In particular, claimed Huntington, "Islam has bloody borders. ${ }^{55}$ In its commitment to peace, then, Western civilisation is superior but dangerously naïve. Huntington does not see civilisational spaces as homogeneous, or at least not the Western space, for he worries that when Asian Americans, Spanish Americans and African Americans become numerically dominant within the United States, then its fundamental WASP values will be compromised. In much the same fashion as the British demographer, David Coleman, he 
believes diversity is dilution. ${ }^{56}$ In his most recent book, Who are We?, he worries about the Catholicisation of American culture by Latinos, a group, he insists, who simply lack the work ethic of the WASPs. ${ }^{57}$ It is clear then, that Huntington's Western civilisation is not only Christian but Protestant, and not only Protestant but White, and not only White but Anglo-Saxon. There is something distinctly racist about this notion of civilisation. ${ }^{58}$ Yet contrary to Huntington's assumption, civilisations have been as likely to learn from as to undermine each other. Religious regions are subject to intense internal conflicts based on ethnicity and diverse Islamic theologies, among other forms of difference, and do not form homogeneous blocs. The major sources of conflict in the world today are more likely to be modern than historical and the biggest obstacle to peace or source of conflict is not the cultural heritage but the hegemonic aspirations of countries and rulers and their apologists. ${ }^{59}$ It is also important to remember, as Ali argues, that at least some of the conflicts within the Muslim world are actually fought by US proxies, that is by groups funded by the United States. ${ }^{60}$ These struggles are not self-evidently Islamic and the peaceable reputation of the world's hegemon is called into question.

Apologists for hegemony present asymmetrical violence as natural, as inevitable. Robert Kaplan's Warrior Politics tells Americans that rights are fundamentally about power and as the country with the most global power, the United States has to accept that it can never apply outside its borders the justice and fairness it has the luxury of practising within its borders. Overseas, the US must often do evil to do good. ${ }^{61}$ Robert Kagan is yet more direct. Kagan was associated with the covert US campaign in support of the Nicaraguan Contras in the mid-1980s and indeed pleaded guilty to two charges of withholding information from Congress in the subsequent Iran-Contra trials. Now one of the Pentagon's favourite pundits, he was, with William Kristol, a co-founder of the very influential Project for a New American Century. He pushes even further than Kaplan the weakening of the legal constraints on power. For Kagan, Europe remains within a 'self-contained world of laws and rules and transnational negotiation and cooperation,' a 'post-historical paradise of peace and relative prosperity. ${ }^{62}$ Kagan is contemptuous of this idealism, proffering, instead, the realism of remaining 'mired in history ... where true security and the defense and promotion of a liberal order still depend on the possession and use of military might. ${ }^{63}$ This is the American view and, when the Europeans were powerful in the period before the First World War, it was the European strategic vision too, for then, Europeans too 'believed in Machtpolitik. ${ }^{64}$ The US National Security Strategy of September 2002 was informed by such thinking and promised that the United States would seek to have the military capacity to prevail against the combined armed forces of the rest of the world put together. ${ }^{65}$ The US currently accounts for about half the global military expenditure and is really now the only truly global armed force on the planet; all other nations have little more 
than regional capacity. This recalls the policy of the United Kingdom in the first decade of the last century. Then, the British wished to have a navy sufficient to prevail against any possible coalition of enemies. ${ }^{66}$

The idea that it is might that makes rights is explicit in Philip Bobbitt's Shield of Achilles. Bobbitt is a nephew of Lyndon Johnson, a Law professor at the University of Texas and has 'served successively as Associate Counsel to the President under Carter, Counsel to the Senate Iran-Contra Committee under Reagan, Counsellor on International Law at the State Department under Bush senior, and Director of Intelligence on the National Security Council under Clinton. ${ }^{67}$ Bobbitt is a constitutional lawyer with an interest in the relations between military strategy and international law. He sees history as a discourse legitimating the appropriate legal order for the current strategic circumstances. Figure 3 is a representation of his argument about the relations between military strategy, international law and historic vision. The column on the left shows the successive military revolutions that appear to drive at least the earlier revolutions in government that produce the series of state-types shown in the column on the right. International law, by and large, develops as an extension of the internal constitutional order of the hegemonic state. In the central column are the strategists who promoted the transformations of state-form or of military tactics, together with the thinkers who located those developments historically and justified the new direction. I have taken the liberty of adding Bobbitt although all he says on the matter is that the market state still awaits its theorist. I have also indicated those theorists that appear to be closest to Bobbitt's own account of each period.

Bobbitt's historical lesson is that 'The State is born in violence: only when it has achieved a legitimate monopoly on violence can it promulgate law: only when it is free of the coercive violence of other states can it pursue strategy. ${ }^{68}$ The paradox is evident. The constitutional lawyer in fact holds out much less hope for law than for force. Thus the Cold War is presented as a noble and generous act through which nuclear deterrence held the ring against communist expansion after the failure of Wilsonian ideas of global democracy was made evident with the Second World War. In this sense, Bobbitt shares much with the perspective of Carl Schmitt in which politics is the realm of the relations between friend and enemy. More broadly, many allege that Schmitt's views have, via his student Leo Strauss, influenced much conservative thinking in the United States. Indeed, Anne Norton now speaks of a Straussian moment in American foreign policy with academics such as Fukuyama, Kristol and Kagan, and policy-makers such as Paul Wolfowitz (undersecretary for Defence), Abram Shulsky (director of the Office of Special Plans, providing Wolfowitz with intelligence connecting Iraq to terrorism), and Leon Kass (chair of the President's Council on Bioethics) all involved in the Bush administration. ${ }^{69}$ 


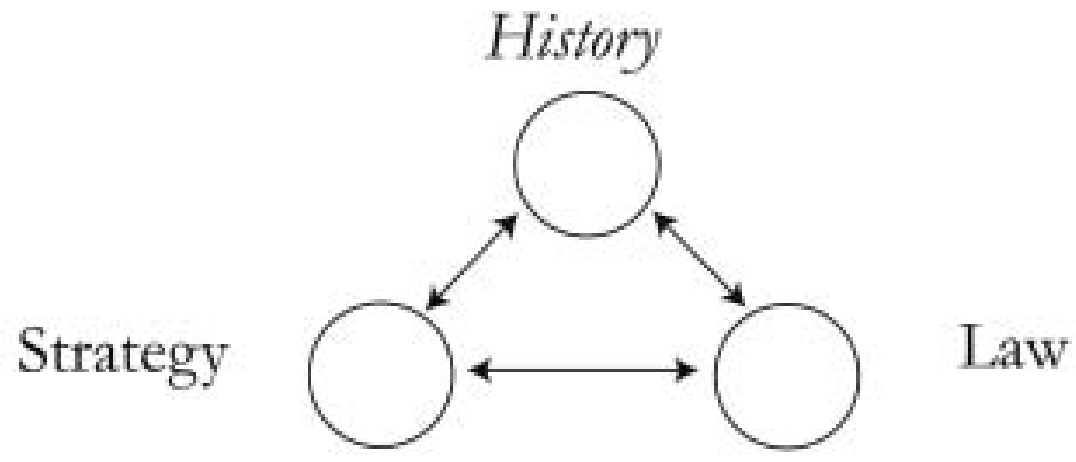

Pikemen, sieges

Archers, battles

Pbilip II 1527-1598/

Augsburg 1555/

Princely states

Infantry,

standing armies

Conscription, shock and awe

Total war

Nuclear weapons

Networked war
Gustavus Adolpbus 1594-1631

Westphalia 1648/

Grotius 1583-1630

Napoleon 1769-1821

Vattel 1714-69

Castlereagh 1769-1822

Bluntscbib 1818-81

Truman 1884-1972

Scbmitt 1888-1985

Gonbacbev 1931-

Bobbitt 1948.
Paris 1990/
larket states

Paris 1990/
Market states

Utrecht 1715/

Territorial states

Vienna 1815/

State nations

Versailles 1919/

Nation states

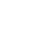

FIGURE 3 A schematic representation of Bobbitt's account of the evolving relations between law, strategy and history. 
Bobbitt argues that in the new world of the market state, the US must adjust its attitude to military strategy and to international law. The market state has emerged because Ronald Reagan and Margaret Thatcher persuaded their electorates that the state could no longer deliver welfare, only opportunity. Thus the market state was born. In a market state, public opinion is influenced by commercially owned media. Indeed, political candidates are funded by special interests. Together these ensure that those who have most at stake in society have most influence. This is a welcome departure from earlier majoritarian forms of democracy. ${ }^{70}$ Until the United States realises the sort of society it has become, it will not evolve an appropriate strategic posture. In the first place, the US has a practical monopoly on the capacity to wage global conflict. Thus it cannot agree to be bound by restrictions, such as those proposed by the International Court of Justice, proposed by states with less capacity to act, and thus less responsibility to act. And the US really must act for it needs to prevent Russia and China from destroying the global environment and Germany and Japan from acquiring nuclear weapons. ${ }^{71}$ The world will accept this American leadership as long as it secures thereby environmental protection and nuclear non-proliferation. ${ }^{72}$ From now on, the United States should act as leader of shifting coalitions of the willing both in war-making and peace-making. By controlling access to strategic intelligence, the United States can make it almost impossible for any nation to prevail in defiance of US interests, even in a regional war. The information umbrella replaces the nuclear umbrella and the United States bears the cost of making the world an unsafe place for terrorists, tyrants and other aggressors. Following the ideology of the market state, the US will intervene in places where the inhabitants do not have the market-given right to explore (commercial) opportunities. The US will police a world in which borders are about markets and not territory. ${ }^{73}$ It will spend money on its armed forces in order to give all peoples of the world the opportunity to choose prosperity instead of being constrained by the 'civilisational apartheid' of such as Islamic theocracies. ${ }^{74}$ In return, the United States runs a trade deficit and those sheltering under its protection, who save money by not having to arm themselves, finance this deficit and thereby own a share of the American economy. ${ }^{75}$

If Bobbitt has identified a universal set of relations between law, strategy and history, then his conclusions about the sort of law and strategy appropriate for our new historical period can follow directly from his account of the new realities. Yet Bobbitt's normative conclusions about the necessity for American force to prevail in the world are only loosely determined by the historical account of global conflict that he provides. In the first place, the causal links between his three realms of law, strategy and history are unstable. His arguments about the strategic future for the United States are based on a 'reality' whereby an ideological innovation in the form of the State (rolling back the state) produces a set of values that in turn 
inform strategy (exporting the capacity to make choices to all places) and law (reinforcing the right of the wealthy and mighty to export opportunity). For the earlier times his arguments were quite different. For those periods, it was innovations in techniques of warfare that influenced the political form of the state and thus the constitutional order of the society of states. In the second place, it is not clear that his market state really does deliver all the benefits he promises. It is surely too sanguine to suggest, as he does, that private firms need limited environmental regulation because they know only too well that consumers will reward them with customer loyalty for having green policies. Nor is it clear that the United States really is taking the lead in securing global environmental protection. In fact, George Bush, according to James Connaughton, Chair of the White House Council on Environmental Quality, 'opposes any treaty or policy that would cause the loss of a single American job. ${ }^{76}$

\section{GLOBAL STRATEGY}

Mackinder saw, then, a world that was becoming unified, in which conflict was an ever-present danger, and in which power and wealth were effectively controlled by a zero-sum game. Mackinder also told his audience at the Royal Geographical Society (RGS) where and how they should act. He said that there was a defensible basket of resources in straddling Western Russia and Eastern Europe that, now linked to a trans-continental railway system, could arm and sustain either a Teutonic or a Slav race should either establish monopoly control over it. Thus Russia and Germany should be kept penned up behind a cluster of buffer states that could prevent either from moving to hold sway across this resource-base. Neither could then control the World Island. Furthermore, Russia should not be allowed access to the eastern Mediterranean for fear it would use its industrial muscle to intervene in European affairs.

Mackinder changed his mind over time about just how far east and south this defensible basket of resources extended but his heartland thesis has been a recurring theme in Anglo-American geopolitics. It has a number of problems and these remain pertinent for those modern strategic thinkers who have recourse to a similar form of argument. There are four central difficulties with this perspective. First, it oversimplifies geopolitical structures by imposing the Manichean friend-enemy view upon a more complex world. Second, it overemphasises the significance of contiguity. Third, it has no faith in markets. Finally, it is liable to disruption both by evolving technologies and by the development of resources in new regions.

David Harvey's account of the informal US Empire in the Middle East shares much with Mackinder's account. It emphasises the lure of a resource basket but now, whereas Mackinder was mainly concerned with coal, iron 
and corn, Harvey says that now 'it's all about oil. ${ }^{77}$ Robert Harvey, former MP and former member of the House of Commons Foreign Affairs Select Committee, notes that the West has pledged $\$ 100$ billion to the development of the Caspian oil reserves. ${ }^{78}$ He claims that Bin Laden's ultimate aim is to deprive the United States of any use of Saudi oil..$^{79}$ Robert Harvey is certainly overstating his case here, for Bin Laden's cultural and religious goals should be taken seriously; he wants to re-establish the medieval Muslim Caliphate through the extension of regimes similar to the Emirate of Afghanistan under the Taliban. ${ }^{80}$ In turn, David Harvey suggests that the US strategic interest in the region is to control the world's oil spigot and thus control the pattern of global development for the next fifty years, restricting the growth of competitors such as China ${ }^{81}$ Michael Klare also argues that modern conflict is essentially about resources: "Whereas international conflict was until recently governed by political and ideological considerations, the wars of the future will largely be fought over the possession and control of vital economic goods - especially resources needed for the functioning of modern industrial societies. ${ }^{82}$

Robert Harvey sees something unique in the current unchallengeable power of the United States as the world's lone hegemon. At present, the US spends half the world's defence budget on its own armed forces as well as selling to its allies a good share of the other arms adrift in the world. The United States, and many commentators, want to believe that there is essentially only one struggle going on in world geopolitics, only one real game in town. This Manichean vision insists that there are no neutrals in the great struggle to come, called, for now, the War on Terror. But the world will not come as clean as strategists think it. The Russians and the Chinese will not allow the United States a monopoly on Gulf or Caspian oil and yet neither shares significant interests with Bin Laden. US interests in the Middle East are shaped by its support for Israel, even where that threatens its access to oil. A nation's geopolitical interests are frequently contradictory and the search for resources is never alone among them. The Bush administration is pro-Israel because of the close ties between many of the neo-conservatives and the Likud Party in Israel and it is pro-Saudi Arabia because of the Bush family's close links with the royal Saud family forged through their joint financial ventures. In August 2001 Prince Bandar went so far as to tell Bush that the alliance between the United States and Saudi Arabia would be aborted since there has been a strategic decision by the United States that its national interest in the Middle East is 100 percent based on Israeli Prime Minister Ariel Sharon. ${ }^{83}$ Bush immediately moved to embrace the opposite pole affirming in a private letter his support for the creation of a Palestinian state. The contradictions are both ideological and material. It does not seem plausible to suggest that religious mobilisation is only ever a cover for resource wars. Nor is it persuasive to argue that resources have only achieved salience as a strategic priority in recent years. 
When Mackinder led the British expeditionary force into South Russia in 1919, ideology and not only resources were at stake. Furthermore, these ideological issues resonated at home as much as abroad. When Beatrice Webb noted that while Mackinder spoke in terms of physical geography and geostrategy he was being made painfully aware of 'another type of momentum - the uprising of the manual workers within each modern state ... it is an uncomfortable shadow falling across his admirable maps of the rise and fall of empires. ${ }^{84}$ While Bobbitt may be exaggerating the clarity of German intentions in the First World War, he is no doubt right that among them was the idea that war would avert the threat of socialist revolution heralded by the Social Democratic electoral victory in $1912 .{ }^{85}$ There is a spatial fetishism in investing spaces with political significance and in exteriorising the sources of threats to the social order: only patriots or traitors (not opponents) within, only friends or enemies (no non-aligned) without.

A second difficulty with this spatial vision is that it over-emphasises the significance of contiguity. In part, and certainly for military strategy, the significance of proximity is a function both of transport costs and of transport technologies. This was what Leo Amery raised when Mackinder read his paper to that evening meeting of the Royal Geographical Society in 1904. Amery, less than six months after the Wright brothers' first successful flight in their 'Kitty Hawk,' asked what significance the airplane might have for military strategy and would it not change the whole concept of a military front as currently understood. This was prescient although there were nowhere near enough airplanes in use in the First World War to unearth the soldiers from their trenches. Similar things are being urged now about the consequences of so-called networked warfare. Bruce Berkowitz argues that information technology, satellite communications and tracking, and guided missiles have rendered the concept of 'the front' obsolete and 'everyone and everything is part of the battlefield today and a potential target. ${ }^{, 86}$ Proximity is further reduced in significance if, as Berkowitz and Barnett believe, smaller units of embedded soldiers will be used for many of the conflicts to come. ${ }^{87}$ Only if the technology of war remains the use of massed armies to defeat opponents arranged on the battlefield will staging posts near battlefields be needed for the congregation of the massed ranks of enormous armies.

Proximity of course matters. Networked soldiers and long range bombing may conquer space in the taking of a country but, as experience in Iraq underlines, in the establishment of a stable regime after the conquest, space and contiguity reassert themselves. Furthermore, pipelines have to pass from oil fields to ports and Klare notes how many relatively small units of US troops are currently posted around the world guarding pipelines. The United States has also taken an interest in restricting pipelines to routes through friendly countries. The boycott on doing business with Iran has meant that "none of the major Caspian oil consortia will be able to construct 
pipelines through Iran. ${ }^{88}$ In this respect, US policy is guided by something like Mackinder's territorial concerns but the United States is much less dependent upon oil from the Middle East than are other world regions. In 1995 only a little over 10\% of the oil exports from the Middle East were for North America even though many of the other oil exports are handled by US companies. ${ }^{89}$ However, the accumulation of wealth in these resourceexporting countries is cause for concern. In the early 1990s, for example, Saudi Arabia received three-quarters of all arms exports from the United Kingdom; and several countries in the Persian Gulf, again most notably Saudi Arabia, have purchased truly awesome amounts of sophisticated weaponry from the United States. ${ }^{90}$ These were sold with a view to helping these countries resist the threat from their neighbours, namely Iraq and Iran. Here, the focus on proximity is the occasion for the proliferation of weaponry to an incredible degree. A related policy was followed when helping the Afghans resist the Soviets, with the result that several hundred surfaceto-air missiles are now unaccounted for, and presumed to be in terrorist hands. If deterrence need not involve extensive ground warfare why, apart from profit, arm so powerfully all these somewhat unstable countries? If anything, the lure of contiguity is justifying policies that will make the region less and not more stable. All too often arms sales protect regimes against internal opposition and further militarise those regimes rendering them resistant to popular democracy. Visions of countries as prone to fall domino-like in sequence, direct attention to threats from neighbours and downplay internal sources of change. Yet this Manichean geography, in which friends are recruited to stand staunch against enemies, has shored up regimes that promise friendship in foreign policy but whose treatment of their own people has been allowed to fall below the radar of the arms-sales calculus.

Finally, the strategic emphasis in these Mackinder-like world-views reinforces the zero-sum logic of closed-space thinking. There is only so much territory in the world and the more of it under our control, the better for us. During the Cold War, this logic justified aiding and abetting regimes of torture and violence in poor countries wherever there was a risk that popular opinion was not going to produce a friendly, that is pro-capitalist, government. A good deal of suffering was visited upon the people of poor countries as a result of a suite of policies that saw communist insurgency where often there was only populist (anti-colonial) nationalism. ${ }^{91}$ In the War on Terror we already see several such unsavoury allies being courted as we countenance and draw intelligence from regimes that now torture Muslims not Communists, as witnessed by the recently replaced British ambassador to Uzbekistan. ${ }^{92}$ Not everybody who is not with us is against us. Furthermore, if we act as if they are, then we may end up producing the behaviour to justify our initial assumption. At present the United States has troops stationed in 120 of the 189 member states of the United Nations. ${ }^{93}$ 
With characteristic candour, Cheney has suggested that there are sixty states against which the United States would be justified in launching pre-emptive strikes. ${ }^{94}$ These are indeed the actions and attitudes of imperialists. Imperialists believe in protecting cheap energy supplies through military effort. The alternatives are to adjust to more expensive energy through energy saving, import substitution and buying supplies from new places. All these will happen as new transportation technologies, perhaps based on hydrogen, are developed, or as more expensive local hydrocarbon sources in shales are exploited, or as new regions, such as West Africa, become major oil exporters. All would reduce the significance of the particular heartland that currently attracts attention.

\section{CONCLUSION}

I have suggested that there are three ways that the current ideologists of the American Empire echo some of the basic features of Mackinder's geopolitical vision. These similarities cannot be put down to the continued interest in Mackinder's writings. Instead, I think that these similarities can be explained by the way they can serve to naturalise empire. The emphasis on a recent historical rupture gives urgency to the proposed geopolitical strategy. Rather than challenge previous ways of seeing the world, this discursive strategy discounts them as no longer relevant. The world, it is suggested, has changed dramatically. Of course, this strategy is always open to the challenge that it exaggerates how new things now are and that it fails to learn the lessons of the recent past. Thus Mackinder exaggerated the extent to which extensive production in the colonies had reached any sort of limit and he exaggerated the extent of Britain's absolute although not relative industrial decline. Yet he needed to argue these things in order to present as essential his proposed transfer of British commercial policy from one of free trade to one of imperial protection. Likewise, the neo-conservatives in the main exaggerate the rupture with the period of the Cold War. There are significant continuities, particularly in the relationship between US foreign policy and US trade policy. However, by arguing that the world has changed in ways that they understand best, they can promote a radical rejection of the multilateralism that they see as an unwelcome constraint upon the actions of the world's remaining hegemon. Furthermore, by presenting the new era as one of closed-space, or globalisation, Mackinder, and his ironic echoes among the neo-conservatives, is able to urge upon audience the need to adopt a global, imperial vision of relentless attention to the internal affairs of every place upon the Earth. Globalisation appears to justify intervention everywhere since everywhere affects everywhere else.

In the second place, Mackinder saw geopolitics as essentially about conflict. These conflicts were rooted in the struggle for survival between 
biologically distinct subsets of the human species. By presenting the struggle as being both inevitable and essential to survival, military strength appears as the only option. What this excludes, of course, is the relationship between external conflict and struggles within society. The external conflict must take precedence over any domestic social or economic issues. In fact, Mackinder urged that domestic issues be addressed in the name of national efficiency in order that in the international struggles to come the British soldier might not be found wanting. There were other contemporary views of Britain's geopolitical circumstances that served different, and more liberal visions of its possible role in the world. ${ }^{95}$ The role of social reform in producing a more effective American population does not appear to be on the political agenda in the United States just now but in most other ways much current geopolitical thinking echoes Mackinder's ideas. The world is seen as a dangerous place. The survival of the United States is seen as in question. Richard Clarke, who was at the time in charge of counter-terrorism strategy for the White House, quotes George Bush as remarking in the aftermath of the attacks of September 11, 2001: 'I don't care what the international lawyers say, we are going to kick some ass. ${ }^{96}$ The country must be put on a war footing so that it can fight the large section of humanity holding a different value system. And again, by putting things in terms of national survival, alternatives can be painted as perhaps unpatriotic. Conflicts within society are almost treason when it is faced with bare survival. Yet these internal divisions will not disappear. Class struggles in the United States continue. Divisions within and between the countries with large Muslim populations do not really register in the clash of civilisations thesis but they are significant nonetheless.

Finally, the echoes of Mackinder are found in the characterisation of military strategies for controlling a resource-defined heartland of the global economy. To some extent it is in part the same region that is currently receiving most attention. ${ }^{97}$ Access to resources is clearly a commercial boon for the companies in the extractive industries and governments have always tried to promote abroad the interests of national companies, but with oil in particular, we are told that securing a supply for Western countries is a matter of national survival. The US memory of the OPEC crisis of 1973 is that the country was held hostage to its need for oil. The military effort to keep cheap supplies flowing is very expensive and it may even save money to reduce dependence on foreign supplies. ${ }^{98}$ Mackinder drew certain conclusions from his study of the geography of natural resources, particularly about the need to deny Russia a warm-water port. He also thought it quite acceptable for the British to assign territories and constitutions to places so that they might serve the higher goal of preserving Anglo-Saxon global hegemony. In other words, local self-determination mattered only where it would serve this goal. Much the same is true now with countries being divided up or kept unwillingly together simply to serve American strategic 
purposes. The division of Iraq into three independent or strongly federal states will be accepted by the United States only as a last resort, regardless of local views.

There are alternatives to the Hobbesian geopolitics of Mackinder and the geostrategists of the War on Terror. We can buy the resources we need without hemming the source regions with military bases and fiercely armed friendly states. We could develop international institutions to arbitrate resource conflicts. In many cases, this would be cheaper for both sides than war or an arms race. We could promote further the work of the International Energy Agency, formed after the 1974 Arab oil boycott to explore alternative ways of sharing oil among Western countries in the event of a similar emergency. ${ }^{99}$ The European Union shows that sovereignty can be shared between states and such pooling arrangements can build trust, and might be tried elsewhere. ${ }^{100}$ The territorial assumption that delimited spaces on the Earth's surface stand for distinct interests has always threatened minorities with majoritarian tyranny and Northern Ireland is not the only place where alternatives need to be found. ${ }^{101}$ Federal solutions help where groups are spatially concentrated but in more integrated societies parity of esteem and protections for minority rights are needed. Before we accept too readily that we face unique 'present dangers ${ }^{102}$ that call for the abridgement of civil liberties at home and the promotion of exemplary wars abroad, we should pause. Also giving papers at the Royal Geographical Society in 1904 was Peter Kropotkin and he presented a very different vision of the potential shape of international relations. ${ }^{103}$ Might not the break in geopolitical history that we can achieve be a step into a world of stronger international institutions, not weaker ones? ${ }^{104}$ Of course, this would mean the most powerful states abridging their room for independent manoeuvre. Yet, they might gain a security and peace dividend thereby. Instead of viewing the world as a zero-sum game of interminable conflict, might we not recognise that co-operation and mutual assistance have played, and continue to play, a significant role in economic development. Nations, regions, religions, and ethnicities are not always and everywhere at each other's throats. Finally, instead of militarising our world still further in the face of geostrategic anxieties, might we not seek to demilitarise our fragile planet. The rich countries could start by buying back the weapons they have sold to the juntas that oppress the poor, and the triumphant West could buy up all the Soviet materiel it can find as part of a new version of Marshall aid and in our collective interest to prevent proliferation. In the United States, Senators Sam Nunn and Dick Lugar have been working to promote a Cooperative Threat Reduction Program for this purpose, and while its efforts in Russia are currently mired in financial scandal, in some Post-Soviet states, such as Belarus, Kazakhstan and the Ukraine, much has been done to re-employ atomic scientists in making safe atomic and chemical stockpiles. ${ }^{105}$ The 
defence spending of the United States in 2003 was about $\$ 400$ billion and $\$ 1$ billion went to the Cooperative Threat Reduction Program. Defence spending in the United States in 2003 was some 15\% above the levels that prevailed during the Cold War. ${ }^{106}$ Mackinder would feel all too at home in the world of the War on Terror, and after a century of world wars and genocide that is really a very depressing reflection.

\section{ACKNOWLEDGEMENTS}

I want to thank Mark Bassin for inviting me to give this paper at the RGS/ IBG conference. I also want to thank the following for advice: Millie Glennon, Mike Heffernan, Simon Reid-Henry, Nic Higgins, Phil Howell, Steve Legg, Nick Megoran, Richard Powell, Gerard Toal, Andy Tucker, Hannah Weston, Charles Withers. I am particularly grateful to one of the referees for a careful and constructive reading that taught me a lot.

\section{NOTES}

1. H. J. Mackinder, 'The Geographical Pivot of History,' Geographical Journal 23/2 (April 1904) pp. $421-437$.

2. K. Dodds and J. Sidaway (eds), Geographical Journal 170/4 (Dec. 2004). Cass 2004).

3. B. W. Blouet (ed.), Global Geostrategy: Mackinder and the Defence of the West (London: Frank

4. http://people.pwf.cam.ac.uk/nwm20/mackinder_cfp, accessed 14 February 2005.

5. P. Kennedy, 'Mission Impossible,' New York Review of Books 51/10 (10 June 2004); idem, 'The Pivot of History,' Guardian (19 June 2004).

6. Bowman to Mackinder, 24 November 1943, RGS Archives, Mackinder Corr. 1940-46.

7. N. Smith, American Empire: Roosevelt's Geographer and the Prelude to Globalization (Berkeley: University of California Press 2003) p. 420.

8. C. S. Gray, 'In Defence of the Heartland: Sir Halford Mackinder and his Critics a Hundred Years on,' Comparative Strategy 23 (2004) 9-25; idem, 'Keeping the Soviets Landlocked: Geostrategy for a Maritime America,' The National Interest (Summer 1986) pp. 24-36.

9. Constable and Co. (London 1919), Henry Holt and Co. (New York 1919), Henry Holt and Co. (New York 1942), Norton (New York 1962), Greenwood Press (Westport 1981), National Defence University Press (Washington DC 1996).

10. Mackinder to Hinks, 23 April 1942, RGS Archives.

11. Mackinder to Hinks, 30 March 1942, RGS Archives.

12. Mackinder to Hinks (note 10).

13. G. Kearns, 'Closed Space and Political Practice: Halford Mackinder and Frederick Jackson Turner,' Environment and Planning D: Society and Space 2 (1984) pp. 23-34.

14. M. Bassin, 'Race contra Space: The Conflict between German Geopolitik and National Socialism,' Political Geography Quarterly 6/2 (1987) pp. 115-134.

15. H. J. Mackinder, 'The Teaching of Geography from an Imperial Point of View,' Geographical Teacher 6 (1911) p. 83.

16. H. J. Mackinder, Democratic Ideals and Reality: A Study in the Politics of Reconstruction (London: Constable and Co. 1919) p. 3.

17. H. J. Mackinder, 'The Great Trade Routes,' Journal of the Institute of Bankers 21 (1900) p. 271.

18. Mackinder, 'Pivot' (note 1) p. 422.

19. Ibid. 
20. H. J. Mackinder, 'Man-Power as a Measure of National and Imperial Strength,' National and English Review 14 (1905) p. 141.

21. Ibid. p. 143.

22. G. Kearns, 'Fin-de-Siècle Geopolitics: Mackinder, Hobson and Theories of Global Closure,' in P. Taylor (ed.), Political Geography of the Twentieth Century (London: Belhaven Press 1993) pp. 9-30.

23. M. Watts, Silent Violence: Food, Famine and Peasantry in Northern Nigeria (Berkeley: University of California Press 1983); M. Davis, Late Victorian Holocausts: El Niño Famines and the Making of the Third World (London: Verso 2001).

24. D. Harvey, The New Imperialism (Oxford: Oxford University Press 2003).

25. R. Cooper, 'Why We still need Empires,' Observer (7 April 2002).

26. Ibid.

27. R. Cooper, The Breaking of Nations: Order and Chaos in the Twenty-First Century (London: Atlantic Books 2003) p. 83.

28. Ibid., pp. $68,66$.

29. Ibid., p. 4.

30. Ibid.

31. R. D. Kaplan, Balkan Ghosts: A Journey through History (New York: St. Martin's Press 1993).

32. M. Glenny, The Rebirth of History: Eastern Europe in the Age of Democracy (Harmondsworth: Penguin 1990).

33. M. Djilas, 'Tito's Last Secret: How Did he Keep the Yugoslavs together?‘ Foreign Affairs (July/ August 1995), http://www.foreignaffairs.org/19950701fareviewessay5057/aleksa-djilas/tito-s-last-secrethow-did-he-keep-the-yugoslavs-together.html, accessed 14 February 2005.

34. G. Smith (ed.), The Nationalities Question in the Post-Soviet States (London: Longman 1996).

35. B. Magas, The Destruction of Yugoslavia: Tracing the Break-up 1980-92 (London: Verso 1993).

36. In conversation with Robert Kaplan (1989), http://www.ralphmag.org/djilasZA.html, accessed 14 February 2005.

37. F. Fukuyama, 'The End of History?' The National Interest 16 (Summer 1989) pp. 3-18.

38. F. Fukuyama, The End of History and the Last Man (London: Penguin 1992) p. 46.

39. Ibid., p. xiii.

40. Ibid., p. 295.

41. M. Curtis, Web of Deceit: Britain's Role in the World (London: Vintage 2003).

42. N. Chomsky, Deterring Democracy (London: Verso 1991).

43. A. Ahmad, 'U.S. Design and Global Complicity,' Frontline (18 January 2003), www.frontlineonnet. com/fl2002/stories/20030131007701800.htm, accessed 30 April 2004.

44. J. Kampfner, Blair's Wars (London: Free Press 2003) p. 55.

45. Curtis (note 41) p. 137.

46. J. Pilger, 'Calling the Kosovo Humanitarians to Account,' Anti-War.Com (9 December 2004), http://www.antiwar.com/orig/pilger.php?articleid=4136, accessed 14 February 2005.

47. N. Clark, 'The Spoils of Another War,' Guardian (21 September 2004), http://www.guardian.co.uk/ Kosovo/Story/0,2763,1309165,00.html, accessed 14 February 2005.

48. S. Huntington, 'The Clash of Civilizations?‘ Foreign Affairs 72/3 (Summer 1993) pp. 22-49.

49. H. J. Mackinder, 'The English Tradition and the Empire: Some Thoughts on Lord Milner's Credo and the Imperial Committees,' United Empire 16 (1925) p. 726.

50. Mackinder, 'Man-Power' (note 20); G. Kearns, 'Halford Mackinder,' Geographers: Biobibliographical Studies 9 (1985) pp. 71-86.

51. Mackinder, 'Pivot' (note 1) p.300.

52. Huntington, 'Clash' (note 48) p. 25.

53. Ibid. p. 22.

54. S. Huntington, The Clash of Civilizations and the Remaking of World Order (London: Simon and Schuster 1997) p. 21.

55. Huntington, 'Clash' (note 48) p. 33.

56. D. Coleman, 'Does Britain Need More Immigrants? No', World Economics 4/2 (2003) pp. $67-85$.

57. S. Huntington, Who are We? The Challenges to America's National Identity (New York: Simon and Schuster 2004).

58. A. A. Mazrui, 'Racial Conflict or Clash of Civilizations? Rival Paradigms for Emerging FaultLines,' in S. Rashid (ed.), "The Clash of Civilizations?" Asian Responses (Dhaka, Bangladesh: The Univer- 
sity Press 1997) pp. 27-37; C. Halim, 'The Clash of Civilizations Revisited: A Confucian Perspective,' in Rashid, Clash pp. 109-125.

59. A. Kalam, 'Huntington and the World Order: Systemic Concern or Hegemonic Vision,' in Rashid, Clash (note 58) p. 50.

60. T. Ali, The Clash of Fundamentalisms: Crusades, Jihads and Modernity (London: Verso 2003 [2002]) p. 309.

61. Kaplan, Warrior Politics: Why Leadership Demands a Pagan Ethos (New York: Random House 2000).

62. R. Kagan, Paradise and Power: America and Europe in the New World Order (London: Atlantic Books 2004 [2003]) p. 3.

63. Ibid.

64. Ibid. p. 8.

65. www.whitehouse.gov/nsc/nss.pdf, accessed 14 February 2005.

66. R. K. Massie, Dreadnought: Britain, Germany, and the Coming of the Great War (New York: Ballantine Books 1992).

67. G. Balakrishnan, 'Algorithms of War,' New Left Review 23 (Sep./Oct. 2003) p. 7.

68. P. Bobbitt, The Shield of Achilles: War, Peace and the Course of History (London: Penguin 2003 [2002]) p. 336.

69. A. Norton, Leo Strauss and the Politics of American Empire (New Haven: Yale University Press 2004).

70. Ibid. p. 239.

71. Bobbitt, Shield (note 68) p. 293.

72. Ibid. p. 309.

73. Ibid. p. 354.

74. T. P. M. Barnett, The Pentagon's New Map: War and Peace in the Twenty-First Century (New York: G. P. Putnam's Sons 2004) p. 32.

75. Ibid. p.308.

76. http://www.commondreams.org/headlines04/1106-07.htm, accessed 1 December 2004.

77. Harvey, (note 24) p.3.

78. Robert Harvey, Global Disorder: How to Avoid a Fourth World War (London: Constable \& Robinson 2003) p. 118.

79. Ibid. p. 123.

80. R. A. Clarke, Against All Enemies: Inside America's War on Terror (London: Free Press 2004) p. 136; Ali, Clash (note 60) p. 110.

81. Harvey (note 24) p. 25.

82. M. T. Klare, Resource Wars: The New Landscape of Global Conflict (New York: Henry Holt \& Co. 2002) p. 213.

83. Craig Unger, House of Bush, House of Saud: The Hidden Relationship between the World's Two Most Powerful Dynasties (London: Gibson Square Books 2004) p. 243.

84. Quoted in W. H. Parker, Mackinder: Geography as an Aid to Statecraft (Oxford: Clarendon Press 1982) pp. 241-242.

85. Bobbitt (note 55) p. 26.

86. B. Berkowitz, The New Face of War: how War will be Fought in the Twenty-First Century (New York: The Free Press 2003) p. 3.

87. Barnett, Pentagon's New Map (note 74).

88. Klare (note 82) p. 100.

89. A. Cordesman, Changing Geopolitics of Energy, Part III (Washington DC: Centre for Strategic and International Studies 1998) p. 21.

90. Klare (note 82) p. 65.

91. Curtis (note 41).

92. C. Murray, 'The Trouble with Uzbekistan,' speech at Royal Institute of International Affairs (8 Nov. 2004), http://www.riia.org/pdf/meeting_transcripts/081104murray.pdf, accessed 1 December 2004.

93. Ali, Clash (note 60) p. xiii.

94. Kampfner, Blair's Wars (note 44) p. 217.

95. Kearns, 'Fin-de-Siècle Geopolitics' (note 22); idem, 'The Political Pivot of Geography,' Geographical Journal 170/4 (Dec. 2004) pp. 337-346.

96. Clarke, Against All Enemies (note 80) p. 24. 
97. S. O'Hara, 'Great Game or Grubby Game? The Struggle for Control of the Caspian,' Geopolitics 9 (2004) pp. 138-160.

98. A. B. Lovins, E. K. Datta, O.-E. Bustnes, J. G. Koomey and N. J. Glasgow, Winning the Oil Endgame: Innovation for Profits, Jobs, and Security (Snowmass, CO: Rocky Mountain Institute 2004).

99. Klare (note 82) p. 224.

100. J. Schell, The Unconquerable World: Power, Non-Violence, and the Will of the People (London: Allen Lane 2003).

101. R. Bourke, Peace in Ireland: The War of Ideas (London: Pimlico 2003).

102. R. Kagan and W. Kristol, Present Dangers: Crisis and Opportunity in American Foreign and Defense Policy (San Francisco: Encounter Books 2000).

103. Kearns, 'Political Pivot' (note 95).

104. G. Monbiot, Age of Consent: a Manifesto for a New World Order (London: Flamingo 2003).

105. J. E. Goodby, D. L. Burghart and C. A. Loeb, Cooperative Threat Reduction for a New Era (Washington, DC: National Defence University 2004).

106. http://www.cdi.org/issues/budget/FY03Highlights-pr.cfm, accessed 14 February 2005. 